University of Nebraska - Lincoln

DigitalCommons@University of Nebraska - Lincoln

\title{
Non-Composted Municipal Solid Waste Processing Byproduct Effect on Soil Reclamation
}

\author{
H. Allen Torbert \\ United States Department of Agriculture, atorbert@ars.usda.gov \\ Dick L. Gebhart \\ U.S. Army Engineer Research and Development Center \\ Ryan R. Busby \\ U.S. Army Engineer Research and Development Center \\ Kenneth N. Potter \\ United States Department of Agriculture \\ Deborah R. Curtain \\ U.S. Army Engineer Research and Development Center
}

Follow this and additional works at: https://digitalcommons.unl.edu/usdaarsfacpub

Part of the Agricultural Science Commons

Torbert, H. Allen; Gebhart, Dick L.; Busby, Ryan R.; Potter, Kenneth N.; and Curtain, Deborah R., "NonComposted Municipal Solid Waste Processing Byproduct Effect on Soil Reclamation" (2007). Publications from USDA-ARS / UNL Faculty. 600.

https://digitalcommons.unl.edu/usdaarsfacpub/600

This Article is brought to you for free and open access by the U.S. Department of Agriculture: Agricultural Research Service, Lincoln, Nebraska at DigitalCommons@University of Nebraska - Lincoln. It has been accepted for inclusion in Publications from USDA-ARS / UNL Faculty by an authorized administrator of DigitalCommons@University of Nebraska - Lincoln. 


\title{
Non-Composted Municipal Solid Waste Processing Byproduct Effect on Soil Reclamation
}

\author{
H. Allen Torbert, ${ }^{1}$ Dick L. Gebhart, ${ }^{2}$ Ryan R. Busby, ${ }^{2}$ \\ Kenneth N. Potter, ${ }^{3}$ and Deborah R. Curtin ${ }^{2}$ \\ ${ }^{1}$ U.S. Department of Agriculture, Agricultural Research Service, National Soil \\ Dynamics Laboratory, Auburn, Alabama, USA \\ ${ }^{2}$ U.S. Army Engineer Research and Development Center, Construction Engineering \\ Research Laboratory, Urbana, Illinois, USA \\ ${ }^{3}$ U.S. Department of Agriculture, Agricultural Research Service, Grassland Soil and \\ Water Research Laboratory, Temple, Texas, USA
}

\begin{abstract}
A new garbage processing technology has been developed that sterilizes and separates inorganic and organic components of municipal solid waste. The non-composted byproduct of this process, Fluff ${ }^{\circledR}$, has the potential to be utilized as a soil amendment to improve soil conditions in highly degraded soils. A study was initiated to evaluate Fluff as a soil amendment for establishing native grasses on disturbed US Army training lands. The Fluff was incorporated into a sandy loam soil at Fort Benning Military Reservation, GA on two sites: a moderately degraded and a highly degraded soil. The Fluff was incorporated at rates of $0,18,36,72$, and $143 \mathrm{Mg} \mathrm{ha}^{-1}$ to assess the effects on soil properties for two growing seasons. The addition of Fluff improved available plant nutrients and soil $\mathrm{pH}$ levels at both sites. Also, Fluff reduced the level of soil bulk density and increased soil concentration of carbon (C) and nitrogen (N). Because no adverse environmental effects were detected and Fluff improved soil physical and nutrient conditions as well as improving perennial grass establishment with increasing application rates, land application of Fluff to degraded US Army training grounds could be considered a viable and beneficial alternative to current waste management practices.
\end{abstract}

Keywords: carbon, municipal solid waste, nitrogen,plant nutrients, soil restoration

Received 9 December 2005; accepted 20 June 2006.

Address correspondence to H. A. Torbert, U.S. Department of Agriculture, Agricultural Research Service, National Soil Dynamics Laboratory, 411 S. Donahue Drive, Auburn, AL 36832, USA. E-mail: atorbert@ars.usda.gov 


\section{INTRODUCTION}

The disposal of municipal solid waste is an ongoing problem in the United States, including United States Army instillations. The Army generated over 1.2 million metric tons of solid waste in the United States in Fiscal Year 2003, but has a limited number of landfills, which increases the costs to shipping garbage off post (Solid Waste Annual Reporting, 2003). One possible method to relieve this waste problem is to reduce the volume of the municipal solid waste or utilize waste in methods other than land filling. A process and equipment that facilitates the rapid separation, volume reduction, and conversion of municipal waste into a sterile organic pulp has been developed. This system grinds up the garbage, separates out ferrous metals, and uses a hydrolyzer with high temperature and pressure steam to break molecular bonds and destroy pathogens (Bouldin and Lawson, Inc. 2000). When hydrolysis is complete, one of the end products is a colorless, odorless, aggregate cellulose pulp. The material is then dried and the organic pulp, called Fluff ${ }^{\circledR}$, is separated from the recyclable glass, metal, and plastic constituents by air classification. After processing, Fluff is unrecognizable as formerly consisting of garbage. The organic byproduct from this process can be land filled at a 30-75\% (depending upon the input materials) reduction in volume (Bouldin Corp, unpublished data, 2001). However, the Fluff material can also be composted and used as a soil amendment or organic fertilizer.

While the resulting Fluff material has been used successfully after composting in the horticulture industry (Croxton et al., 2004), Fluff may also be an effective soil amendment before composting to improve soil physical and chemical properties, thereby enhancing land rehabilitation efforts. Since most contaminants and pathogens have been removed, the Fluff material could bypass the composting process and eliminate the most negative aspects of large-scale composting: the time and facilities requirements and resulting problems with leachate, odors, pests, and pathogen exposure.

The Army has almost 5 million hectares of land in the United States, including 73 installations with greater than 4,000 hectares each. Large blocks of this land are in need of rehabilitation due to Army training activity, but often lack sufficient topsoil, organic matter, and nutrients required for successful rehabilitation. Due to the expenses involved with overcoming these limitations, a cheap alternative material is needed. Additionally, the Army is mandated by numerous federal, agency, and departmental laws to control water and air pollution, maintain ecosystem sustainability, protect native biological diversity, and promote beneficial reuse practices whenever possible. For example, Executive Order 13101, "Greening the Government through Waste Prevention, Recycling, and Federal Acquisition", requires executive agencies to "incorporate waste prevention and recycling in the agency's daily operations and work to increase and expand markets for recovered materials.' Therefore, the Army has enough acreage to support large-scale land utilization of organic waste 
byproducts (DoD, 2001) and the need to recycle waste products where feasible. By diverting organic matter from landfills to degraded training lands, the Army could incorporate reuse of municipal waste into land management, decrease waste disposal costs, and improve land rehabilitation efforts on Army training and testing ranges.

An effort to utilize organic waste byproducts by the Army could be greatly enhanced if the need for large scale composting facilities for municipal waste could be eliminated. However, municipal solid wastes are not immediately suited for direct land application because they are very resistant to decomposition and can create environmental problems (Edwards, 1997; Karlen et al., 1998). The use of a highly processed organic pulp such as Fluff could divert organic matter from landfills to degraded training lands. While many similarities exist between the land application of other agricultural and industrial waste products such as poultry litters, animal manures, and composted biosolids, the generation of cellulosic pulp is a relatively new process. The Fluff is unique in both origin and physical attributes when compared to other soil amendments, and land application studies have yet to be conducted.

One potential problem with an non-composted organic material is the high carbon: nitrogen $(\mathrm{C}: \mathrm{N})$ ratio, which could create a soil environment with low $\mathrm{N}$ availability. Perennial warm season grasses, such as those native to the Tallgrass Prairie of North America, are well adapted to harsh environmental conditions, including low $\mathrm{N}$ availability, giving them a competitive advantage in poor soils (Jung et al., 1988; Wilson and Gerry, 1995; Skeel and Gibson, 1996; Levy et al., 1999). These grasses are used abundantly in reclamation, as they develop extensive root systems that penetrate deep into soils, providing a very effective safeguard against erosion (Drake, 1980). This study examined whether an noncomposted material with a high $\mathrm{C}: \mathrm{N}$ ratio such as Fluff could be beneficial as an environmentally friendly organic soil amendment that can improve soil condition for the establishment of native grasses.

\section{MATERIALS AND METHODS}

Field studies were established in February 2003, to determine the effect of utilizing cellulose pulp from a highly processed municipal organic waste as a soil amendment for improving soil quality, plant growth, and revegetation success on degraded Army training lands. The cellulose pulp used was the output material from a grinding and hydrolyzing process for municipal waste products, which produces an "aggregate cellulose pulp" (Fluff ${ }^{\circledR}$ ) (Bouldin \& Lawson, Inc. 2000).

Component properties of Fluff that are significant to agricultural are presented in Table 1. Fluff has a near-neutral $\mathrm{pH}$ and a $\mathrm{C}: \mathrm{N}$ ratio of 30, indicating that it will readily decompose. A germination test was also performed to determine any inhibitory effects of Fluff on native grass germination. Fluff rates up 
Table 1

Fluff properties significant to agriculture

\begin{tabular}{lc}
\hline $\mathrm{pH}$ & 6.5 \\
$\mathrm{C}: \mathrm{N}$ & 32 \\
$\mathrm{C}(\%)$ & 39.8 \\
$\mathrm{~N}(\%)$ & 1.26 \\
$\mathrm{P}\left(\mathrm{mg} \mathrm{kg}^{-1}\right)$ & 1900 \\
$\mathrm{~K}\left(\mathrm{mg} \mathrm{kg}^{-1}\right)$ & 2170 \\
$\mathrm{Ca}\left(\mathrm{mg} \mathrm{kg}^{-1}\right)$ & 13600 \\
$\mathrm{Mg}\left(\mathrm{mg} \mathrm{kg}^{-1}\right)$ & 1400 \\
$\mathrm{Fe}\left(\mathrm{mg} \mathrm{kg}^{-1}\right)$ & 2460 \\
$\mathrm{Mn}\left(\mathrm{mg} \mathrm{kg}^{-1}\right)$ & 130 \\
$\mathrm{Zn}\left(\mathrm{mg} \mathrm{kg}^{-1}\right)$ & 234 \\
$\mathrm{~B}\left(\mathrm{mg} \mathrm{kg}^{-1}\right)$ & 35 \\
$\mathrm{Cu}\left(\mathrm{mg} \mathrm{kg}^{-1}\right)$ & 47.7 \\
$\mathrm{Co}\left(\mathrm{mg} \mathrm{kg}^{-1}\right)$ & 2.0 \\
$\mathrm{Na}\left(\mathrm{mg} \mathrm{kg}^{-1}\right)$ & 5169 \\
\hline
\end{tabular}

to $11.2 \mathrm{Mg} \mathrm{ha}^{-1}$ had no effect on germination, however, pure Fluff was not an effective germination medium (Busby, 2003).

Studies were established at two sites on Fort Benning Military Reservation, GA, based on soil mapping units, past training history, and level of degradation. The sites chosen were approximately 0.4 ha in size and were designated as "Dove Field" and "Borrow Pit." The Dove Field site was a moderately degraded sandy loam soil (loamy, kaolinitic, thermic Grossarenic Kandiudults) and was considered to be more productive (based on site evaluations) than the highly degraded Borrow Pit soil (highly disturbed fine-loamy, kaolinitic, thermic Typic Kandiudults). At these sites, treatment plots consisted of a control where nothing was done, a control with revegetation only, and application of Fluff at rates of $0,18,36,72$, and $143 \mathrm{Mg}^{-1}$ with revegetation. Fluff was hand weighed and spread in $3.7 \times 4.9 \mathrm{~m}\left(18 \mathrm{~m}^{2}\right)$ plots separated by a 2.4 $\mathrm{m}$ wide buffer to avoid crosscontamination. Plot preparation included plowing, application of Fluff, replowing to incorporate Fluff to a depth of 10-20 $\mathrm{cm}$, followed by seed drilling of native grass species seed mixes and standard seed bed preparation techniques. Native grasses were selected based on previous research, suitability, adaptability, availability, cost, and photosynthetic pathway. Three C4 grasses: Andropogon gerardii (Big Bluestem), Panicum virgatum (Switchgrass), and Sorghastrum nutans (Indiangrass) and one C3 grass: Elymus virginicus (Virginia Wildrye) were selected. Vegetation sampling, including plant biomass, plant nutrient composition, plant species composition, and basal vegetative cover were measured at the end of the growing seasons in 2003 and 2004. Plant biomass was collected by clipping 5 random samples per plot to a height of $1 \mathrm{~cm}$ using $30 \times 60 \mathrm{~cm}$ quadrants. Detailed analysis of plant vegetation responses are reported elsewhere (Busby et al., 2006). 
Soil samples were obtained each year using two soil cores $(3.8 \mathrm{~cm}$ diameter) from each plot collected with a custom-made telescoping soil coring device assisted by a modified commercial hydraulic post driver mounted to the front of a small tractor. The tractor hydraulic system powered both the telescoping device and the post driver (Prior et al., 2004). Soil samples were obtained at depths of $0-5,5-10,10-20$, and 20-30. Soil bulk density was determined on each soil sample by calculating total soil dry weight within the volume of each soil sample. Subsamples of the soils were dried $\left(55^{\circ} \mathrm{C}\right)$, ground to pass a $0.15 \mathrm{~mm}$ sieve, and analyzed for total $\mathrm{N}$ and $\mathrm{C}$ concentration on LECO Truspec (LECO Corp., Saint Joseph, $\mathrm{MI}^{1}$ ). Soil samples were also analyzed for extractable boron $(\mathrm{B})$, barium $(\mathrm{Ba})$, calcium $(\mathrm{Ca})$, cadmium $(\mathrm{Cd})$, cobalt $(\mathrm{Co})$, chromium $(\mathrm{Cr})$, copper $(\mathrm{Cu})$, iron $(\mathrm{Fe})$, potassium $(\mathrm{K})$, magnesium $(\mathrm{Mg})$, manganese $(\mathrm{Mn})$, sodium $(\mathrm{Na})$, nickel $(\mathrm{Ni})$, phosphorus $(\mathrm{P})$, lead $(\mathrm{Pb})$, and zinc (Zn), using procedures outlined by Hue and Evans (1986). Briefly, the soils were extracted using Mehlich 1 extractant (Mehlich, 1953) and measured by inductive coupled plasma spectrophotometry (Spectro CirOS, FCSMi, Spectro Analytical Instruments, Inc. Fitchburg, MA). Soil pH (McLean, 1982) was also measured from these soil samples.

The study was a completely randomized block design replicated four times. Statistical analysis was performed using the Statistical Analysis System (Littel et al., 1996) and means were separated at an a priori 0.05 significance probability level. Statistical analysis was also conducted by developing regression equations of soil $\mathrm{C}$ and $\mathrm{N}$ concentrations and soil $\mathrm{pH}$ versus Fluff application rate for each study site.

\section{RESULTS AND DISCUSSION}

Prior to any experimentation, the Fluff was intensively analyzed for levels of 184 regulated compounds, including 11 heavy metals, 113 semi-volatile and 60 volatile organic, 6 pesticides, 2 herbicides, and dioxin compounds to determine any potential regulatory limitations. This testing of the finished pulp detected 9 heavy metals, 3 semi-volatile, and 3 volatile organic compounds, but did not show any contaminant concentration that exceeded Federal or State EPA standards (Busby et al., 2006). The detected organic compounds are regulated due to risks associated with workplace exposure and concentrated industrial effluent, but due to their volatile nature and rapid turnover in the environment they are not regulated for land application. Fluff was found to have heavy metal concentrations at least an order of magnitude below their respective ceiling limits

\footnotetext{
${ }^{1}$ Names are necessary to report factually on available data: however, the USDA neither guarantees nor warrants the standard of the production; the use of the name by USDA implies no approval of the product to the exclusion of others that may be suitable.
} 
established for land application of heavy metals in biosolids ( U.S. Government 40 C.F.R. Part 503, 1999). Lead would be the limiting factor as it reached the maximum biosolids limit at the lowest application rate. This limit would be reached with a maximum annual rate of $229 \mathrm{Mg}$ Fluff ha $^{-1}$ and a maximum cumulative application rate of $4587 \mathrm{Mg} \mathrm{ha}^{-1}$.

A preliminary study of the application of Fluff on a silt loam soil indicated that native grass establishment was enhanced and basal cover of planted perennial grasses was increased (Busby et al., 2006). An increase in soil concentration of $\mathrm{Pb}$ and $\mathrm{P}$ was noted with increasing rates of Fluff application. The increase in lead was insignificant $\left(1.5 \mathrm{mg} \mathrm{kg}^{-1}\right.$ for the highest Fluff rate) with respect to established regulatory limits, while the increase in soil $\mathrm{P}$ concentrations alleviated an apparent $\mathrm{P}$ deficiency in the study site soils.

Component properties of Fluff that are significant to agriculture are presented in Table 1. Fluff has a near-neutral $\mathrm{pH}$ and a $\mathrm{C}: \mathrm{N}$ ratio of 30, indicating that it will readily decompose. A germination test was also performed to determine any inhibitory effects of Fluff on native grass germination. Fluff rates up to $11.2 \mathrm{Mg} \mathrm{ha}^{-1}$ had no effect on germination; however, pure Fluff was not an effective germination medium (Busby, 2003) due to the hydrophobic nature of the pure fluff.

Application of Fluff at both Fort Benning sites (Dove Field and the Borrow Pit), resulted in improved revegetation of the native grasses as reported by Busby et al. (2006). They reported a positive response to Fluff application for plant biomass, plant nutrient composition, plant species composition, and basal vegetative cover. Detailed analysis of revegetation response to Fluff can be found in Busby et al. (2006); briefly, increased biomass production was noted with increasing Fluff application up to $143 \mathrm{Mg} \mathrm{ha}^{-1}$ in both years sampled (Table 2).

Table 2

Biomass yields as affected by Fluff application for the Dove Field and Borrow Pit study sites in 2003 and 2004

\begin{tabular}{lllllr}
\hline & \multicolumn{4}{c}{$\left(\mathrm{g} \mathrm{m}^{-2}\right)$} \\
\cline { 2 - 3 } Mg ha $^{-1}$ & \multicolumn{2}{c}{ Dove Field } & & \multicolumn{2}{c}{ Borrow Pit } \\
\cline { 2 - 3 } \cline { 5 - 6 } Fluff Rate & 2003 & 2004 & & 2003 & 2004 \\
\hline Unseeded Control & 243 & 291 & & 0 & 0 \\
0 & 269 & 392 & & 18 & 14 \\
18 & 344 & 617 & & 46 & 90 \\
64 & 428 & 613 & & 73 & 122 \\
72 & 468 & 749 & & 202 & 403 \\
143 & 539 & 1059 & 345 & 582 \\
\hline
\end{tabular}

${ }^{\dagger}$ Values represent means of 4 replications. 
Table 3

Soil bulk density in the $0-5 \mathrm{~cm}$ soil depth for the dove field and borrow pit study sites in 2003 and $2004^{\dagger}$

\begin{tabular}{rcr}
\hline & \multicolumn{2}{c}{$\left(\mathrm{g} \mathrm{cm}^{-3}\right)$} \\
\cline { 2 - 3 } Mg ha & \\
Fluff rate & 2003 & 2004 \\
\hline & Dove Field \\
0 & $1.56 \mathrm{a}$ & $1.42 \mathrm{a}$ \\
18 & $1.47 \mathrm{a}$ & $1.49 \mathrm{a}$ \\
64 & $1.48 \mathrm{a}$ & $1.44 \mathrm{a}$ \\
72 & $1.41 \mathrm{a}$ & $1.36 \mathrm{a}$ \\
143 & $1.17 \mathrm{~b}$ & $1.12 \mathrm{~b}$ \\
& Borrow Pit & \\
0 & $1.82 \mathrm{a}$ & $1.67 \mathrm{a}$ \\
18 & $1.75 \mathrm{a}$ & $1.65 \mathrm{~b}$ \\
64 & $1.68 \mathrm{a}$ & $1.59 \mathrm{~b}$ \\
72 & $1.41 \mathrm{~b}$ & $1.53 \mathrm{bc}$ \\
143 & $1.22 \mathrm{~b}$ & $1.45 \mathrm{c}$ \\
\hline
\end{tabular}

${ }^{\dagger}$ Values represent means of 4 replications.

The addition of the Fluff had an impact on the soil bulk density level in the surface soil $(0-5 \mathrm{~cm})$ (Table 3$)$. While no significant difference was noted for depths below $0-5 \mathrm{~cm}$ at either study site, the impact of improving the soil bulk density in the soil surface would be important for native grass establishment. At the Dove Field, the soil bulk density was in the range of $1.56 \mathrm{~g} \mathrm{~cm}^{-3}$ at the initiation of the study, but with the application of $143 \mathrm{Mg} \mathrm{ha}^{-1}$ Fluff, soil bulk density was drastically reduced to $1.17 \mathrm{~g} \mathrm{~cm}^{-3}$. An even larger impact was observed with the soil at the Borrow Pit site. The initial level of soil bulk density was $1.83 \mathrm{~g} \mathrm{~cm}^{-3}$, which could be detrimental to plant root growth (Glinski and Lipiec, 1990). The addition of the Fluff at this site reduced the soil bulk density to $1.22 \mathrm{~g} \mathrm{~cm}^{-3}$ with the application of $143 \mathrm{Mg} \mathrm{ha}^{-1}$.

In the second year of the study, a further reduction in the level of soil bulk density was generally observed at both study sites at the $0-5 \mathrm{~cm}$ depth (Table 3). As was observed in the first year, an increasing rate of Fluff application resulted in a soil bulk density decrease. This was likely due to the increased plant rooting from the continued establishment of the native grasses during the second growing season. With an increased plant root mass from grass establishment, bulk density was reduced as the plants created root channels through the compacted soil. The level of reduction observed with Fluff application would have an important impact on soil condition at both locations. Although the impact of bulk density is affected by both soil type and plant species, soil bulk densities above $1.5 \mathrm{~g} \mathrm{~cm}^{-3}$ have generally been shown to be detrimental to root growth and plant yield (Glinski and Lipiec, 1990). The reduction in the level 
of bulk density observed in this first year would be much more conducive to both plant establishment and root growth of the native grasses. The soil bulk density levels observed from second year soil sampling indicates that the soil physical condition had been substantially improved and that this improvement would likely persist. The improvement in soil bulk density alone would indicate that the degraded soil conditions commonly associated with US Army training activities could be substantially ameliorated with high Fluff application rates.

The ability of the soil to provide plant nutrients are controlled by many factors, such as organic matter content, soil $\mathrm{pH}$, and soil texture (Potash and Phosphate Institute, 2003). Many of these factors, such as soil organic matter content, are reduced in degraded soils, thereby reducing the ability of the soil to provide adequate plant nutrient supply. As noted, the Fluff contained substantial amounts of essential plant nutrients, which would have been present with the application of the Fluff (Table 1). However, these nutrients would not necessarily be available for plant uptake, depending on the condition of the soil, particularly the soil $\mathrm{pH}$ level, and the decomposition and release of the nutrients in the Fluff (Potash and Phosphate Institute, 2003).

Extractable soil nutrients, measured at the end of the first growing season for both sites, are shown in Table 4. The application of Fluff increased extractable nutrients in the surface soil layer at both sites. At the Dove Field, a less degraded soil compared to the Borrow Pit, Fluff application resulted in a significant impact on extractable nutrient concentrations for $\mathrm{P}, \mathrm{B}, \mathrm{Ca}, \mathrm{Co}$, and $\mathrm{Zn}$ in the $0-5 \mathrm{~cm}$ soil layer. The soil concentration of $\mathrm{Ca}$ and $\mathrm{P}$ were particularly improved with the application of Fluff, with Ca concentrations increasing from 195 to 1835 $\mathrm{mg} \mathrm{kg}^{-1}$ and $\mathrm{P}$ concentrations increasing from 29 to $145 \mathrm{mg} \mathrm{kg}^{-1}$ with the application of $143 \mathrm{Mg} \mathrm{ha}^{-1}$ of Fluff. The concentration of extractable $\mathrm{P}$ in soil often limits plant production in agricultural scenarios, which results in the need to add $\mathrm{P}$ fertilizer to improve soil fertility (Potash and Phosphate Institute, 2003).

At the Borrow Pit, the soil was extremely degraded, resulting in almost no vegetation at the site at the start of the study. At this site, the initial soil fertility level was extremely low. The application of Fluff resulted in a significant increase in the extractable soil nutrients $\mathrm{B}, \mathrm{Ca}, \mathrm{Co}, \mathrm{Cu}, \mathrm{Fe}, \mathrm{K}, \mathrm{Mg}, \mathrm{Mn}, \mathrm{P}$, and $\mathrm{Zn}$ (Table 4). This increase was likely due not only to the addition of these nutrients with the Fluff (Table 1), but also due to the improvement in the soil $\mathrm{pH}$ level that was observed with increasing levels of Fluff application (Figure 1). As soil $\mathrm{pH}$ level is increased toward neutral, the availability of most plant nutrients improves (Potash and Phosphate Inst., 2003). The concentration of extractable $\mathrm{P}, \mathrm{K}, \mathrm{Mg}$, and $\mathrm{Ca}$ are especially important for plant nutrition, and were notably impacted by increased Fluff application, with 62, 5, 77, and 425 fold increases in $\mathrm{P}, \mathrm{K}, \mathrm{Mg}$, and $\mathrm{Ca}$ concentration levels, respectively, with the application of $143 \mathrm{Mg} \mathrm{ha}^{-1}$ Fluff. The initial levels of soil $\mathrm{P}$ and $\mathrm{K}$ concentration measured at this site were extremely low and would result in severe plant deficiencies of these nutrients with prolonged growth (Auburn University Soil Testing, 2005). 








Figure 1. Regression relationships of Fluff application rate to soil $\mathrm{pH}$ measured at $0-5$, 5-10, 10-20, and 20-30 cm soil depth at the Dove Field and Borrow Pit study sites in 2003 (See Table 6 for regression equations and $\mathrm{r}^{2}$ values).

The addition of Fluff increased the soil extractable levels of plant macro- and micro-nutrients to levels that would allow adequate plant growth.

Soil extracts were also analyzed for concentration of the heavy metals $\mathrm{Cd}$, $\mathrm{Cr}, \mathrm{Ni}$, and $\mathrm{Pb}$ (Table 5), which have USEPA limits for biosolids application ( U.S. Government 40 C.F.R. Part 503, 1999). At the Dove Field, the concentration of Cd was significantly increased with increasing Fluff application. The concentration of $\mathrm{Pb}$ increased, but only at the highest application rate was the concentration found to be significantly higher than the initial soil condition. At the Borrow Pit, the concentration of Cd was found to be significantly increased with increasing application rate of Fluff. The concentration of $\mathrm{Cr}, \mathrm{Ni}$, and $\mathrm{Pb}$ were also increased, but only at the highest application rate where there were significant differences compared to the initial soil conditions (Table 5). None of the heavy metal concentration found in the soil would be of concern in terms of the maximum cumulative loading limits as regulated for biosolids (U.S. Government 40 C.F.R. Part 503, 1999). 
Table 5

Soil extractable heavy metal concentrations in the $0-5 \mathrm{~cm}$ soil depth for the Dove Field and Borrow Pit study sites (2003) $)^{\dagger}$

\begin{tabular}{|c|c|c|c|c|c|}
\hline \multirow{2}{*}{$\begin{array}{l}\mathrm{Mg} \mathrm{ha}^{-1} \\
\text { Fluff rate }\end{array}$} & \multicolumn{5}{|c|}{$\left(\mathrm{mg} \mathrm{kg}^{-1}\right)$} \\
\hline & $\mathrm{Ba}$ & $\mathrm{Cd}$ & $\mathrm{Cr}$ & $\mathrm{Ni}$ & $\mathrm{Pb}$ \\
\hline \multicolumn{6}{|c|}{ Dove Field } \\
\hline 0 & $0.63 \mathrm{a}$ & $0.05 \mathrm{a}$ & $0.03 \mathrm{a}$ & $0.08 \mathrm{a}$ & $0.00 \mathrm{a}$ \\
\hline 18 & $0.47 \mathrm{a}$ & $0.12 \mathrm{~b}$ & $0.11 \mathrm{a}$ & $0.16 \mathrm{a}$ & $0.27 \mathrm{a}$ \\
\hline 64 & $0.45 \mathrm{a}$ & $0.08 \mathrm{ab}$ & $0.11 \mathrm{a}$ & $0.45 \mathrm{a}$ & $0.03 \mathrm{a}$ \\
\hline 72 & $0.45 \mathrm{a}$ & $0.10 \mathrm{~b}$ & $0.11 \mathrm{a}$ & $0.22 \mathrm{a}$ & $0.02 \mathrm{a}$ \\
\hline 143 & $0.52 \mathrm{a}$ & $0.21 \mathrm{c}$ & $0.28 \mathrm{a}$ & $0.50 \mathrm{a}$ & $0.80 \mathrm{~b}$ \\
\hline \multicolumn{6}{|c|}{ Borrow Pit } \\
\hline 0 & $0.47 \mathrm{a}$ & $0.01 \mathrm{a}$ & $0.01 \mathrm{a}$ & $0.02 \mathrm{a}$ & $0.15 \mathrm{a}$ \\
\hline 18 & $0.54 \mathrm{a}$ & $0.01 \mathrm{a}$ & $0.04 \mathrm{a}$ & $0.10 \mathrm{a}$ & $0.31 \mathrm{a}$ \\
\hline 64 & $0.75 \mathrm{a}$ & $0.01 \mathrm{a}$ & $0.02 \mathrm{a}$ & $0.05 \mathrm{a}$ & $0.21 \mathrm{a}$ \\
\hline 72 & $1.04 \mathrm{a}$ & $0.07 \mathrm{~b}$ & $0.14 \mathrm{a}$ & $0.31 \mathrm{a}$ & $0.87 \mathrm{a}$ \\
\hline 143 & $1.97 \mathrm{~b}$ & $0.13 \mathrm{c}$ & $0.35 \mathrm{~b}$ & $0.77 \mathrm{~b}$ & $2.26 \mathrm{~b}$ \\
\hline
\end{tabular}

\footnotetext{
${ }^{\dagger}$ Values represent means of 4 replication from composited soil samples taken from each plot.
}

The application of the Fluff had a large impact on the soil $\mathrm{pH}$, especially in the soil sampled after the first growing season. The Fluff would not be a liming material, but because of the near neutral $\mathrm{pH}$ and large $\mathrm{Ca}$ content of the Fluff material, the application of Fluff raised the soil $\mathrm{pH}$. In the first year of the study, the soil $\mathrm{pH}$ had a linear response to increasing Fluff application at both study sites (Table 6, Figure 1). At $0-5 \mathrm{~cm}$ depth of the Dove Field, the control plots indicated that the soil $\mathrm{pH}$ was approximately 6.4 , which increased to the level of about 7.2 with the application of $143 \mathrm{Mg} \mathrm{ha}^{-1}$ of Fluff. For the highly degraded soil at the Borrow Pit, the soil $\mathrm{pH}$ was very low (5.3) for the control plots at the $0-5 \mathrm{~cm}$ depth. The application of the Fluff had a dramatic impact on the $\mathrm{pH}$ level measured, with a linear increase up to a level of approximately 7.4. This was likely due not only to the much lower initial soil $\mathrm{pH}$ level at this site, but also to the lower buffering capacity of this highly degraded soil. The increases in soil $\mathrm{pH}$ were not limited to the top soil layer, and a significant linear increase in soil $\mathrm{pH}$ was observed down to the $30-60 \mathrm{~cm}$ soil depth layer at both locations (Table 6, Figure 1). This increase in soil $\mathrm{pH}$ could be critical to the establishment of native grasses. Soil $\mathrm{pH}$ at or below the 5.3 level would be very detrimental to plant growth, resulting in nutrient deficiencies and potential Al toxicity (Potash and Phosphate Inst., 2003). The level of soil pH observed in the control plots would partially explain the complete failure of plant growth that was observed in those plots (Table 2), and raising the soil $\mathrm{pH}$ level would explain much of the positive revegetation response that was observed at this location. 
Table 6

Regression equations describing relationship of Fluff application rate vs. and soil pH in 2003 and 2004 at $0-5,5-10,10-20$, nd 20-30 cm soil depth

\begin{tabular}{cccc}
\hline Depth & Site & Equation & $\mathrm{r}^{2}$ \\
\hline & & Soil pH 2003 & \\
$0-5$ & Dove Field & $\mathrm{pH}=6.42+0.0129 *$ Fluff & 0.590 \\
$5-10$ & & $\mathrm{pH}=6.30+0.0114 *$ Fluff & 0.268 \\
$10-20$ & & $\mathrm{pH}=6.03+0.0105 *$ Fluff & 0.226 \\
$20-30$ & & $\mathrm{pH}=5.69+0.0129 *$ Fluff & 0.264 \\
$0-5$ & Borrow Pit & $\mathrm{pH}=5.35+0.0315 *$ Fluff & 0.680 \\
$5-10$ & & $\mathrm{pH}=5.48+0.0357 *$ Fluff & 0.718 \\
$10-20$ & & $\mathrm{pH}=5.15+0.0366 *$ Fluff & 0.834 \\
$20-30$ & & $\mathrm{pH}=5.08+0.0305 *$ Fluff & 0.745 \\
& & Soil pH 2004 & \\
$0-5$ & Dove Field & $\mathrm{NS}$ & \\
$5-10$ & & $\mathrm{pH}=6.13+0.0123 *$ Fluff & 0.269 \\
$10-20$ & & $\mathrm{pH}=5.91+0.0095 *$ Fluff & 0.234 \\
$20-30$ & & NS & \\
$0-5$ & Borrow Pit & $\mathrm{pH}=5.32+0.0252 *$ Fluff & 0.608 \\
$5-10$ & & $\mathrm{pH}=5.37+0.0316 *$ Fluff & 0.682 \\
$10-20$ & & $\mathrm{pH}=5.27+0.0316 *$ Fluff & 0.773 \\
$20-30$ & & $\mathrm{pH}=5.19+0.0293 *$ Fluff & 0.702 \\
\hline
\end{tabular}

\section{Table 7}

Regression equations describing relationship of Fluff application rate vs. soil $\mathrm{C}$ and $\mathrm{N}$ concentration at $0-5,5-10,10-20$, nd 20-30 $\mathrm{cm}$ soil depth.

\begin{tabular}{cccc}
\hline Depth & Site & Equation & $\mathrm{r}^{2}$ \\
\hline & & Total C Concentration & \\
$0-5$ & Dove Field & $\mathrm{C}=1.306+0.0412 *$ Fluff & 0.581 \\
$5-10$ & & $\mathrm{NS}$ & \\
$10-20$ & & $\mathrm{NS}$ & \\
$20-30$ & & $\mathrm{NS}$ & \\
$0-5$ & Borrow Pit & $\mathrm{C}=0.219+0.0281 *$ Fluff & 0.468 \\
$5-10$ & & $\mathrm{C}=0.263+0.0049 *$ Fluff & 0.348 \\
$10-20$ & & $\mathrm{C}=0.200+0.0007 *$ Fluff & 0.324 \\
$20-30$ & & $\mathrm{C}=0.187+0.0004 *$ Fluff & 0.537 \\
& & Total N Concentration & \\
$0-5$ & Dove Field & $\mathrm{N}=0.061+0.0044 *$ Fluff & 0.589 \\
$5-10$ & & $\mathrm{NS}$ & \\
$10-20$ & & $\mathrm{NS}$ & \\
$20-30$ & & $\mathrm{NS}$ & \\
$0-5$ & Borrow Pit & $\mathrm{N}=0.008+0.0014 *$ Fluff & 0.463 \\
$5-10$ & & $\mathrm{~N}=0.015+0.0004 *$ Fluff & 0.350 \\
$10-20$ & & $\mathrm{~N}=0.007+0.0002 *$ Fluff & 0.343 \\
$20-30$ & & $\mathrm{~N}=0.007+0.0002 *$ Fluff & 0.410 \\
\hline
\end{tabular}



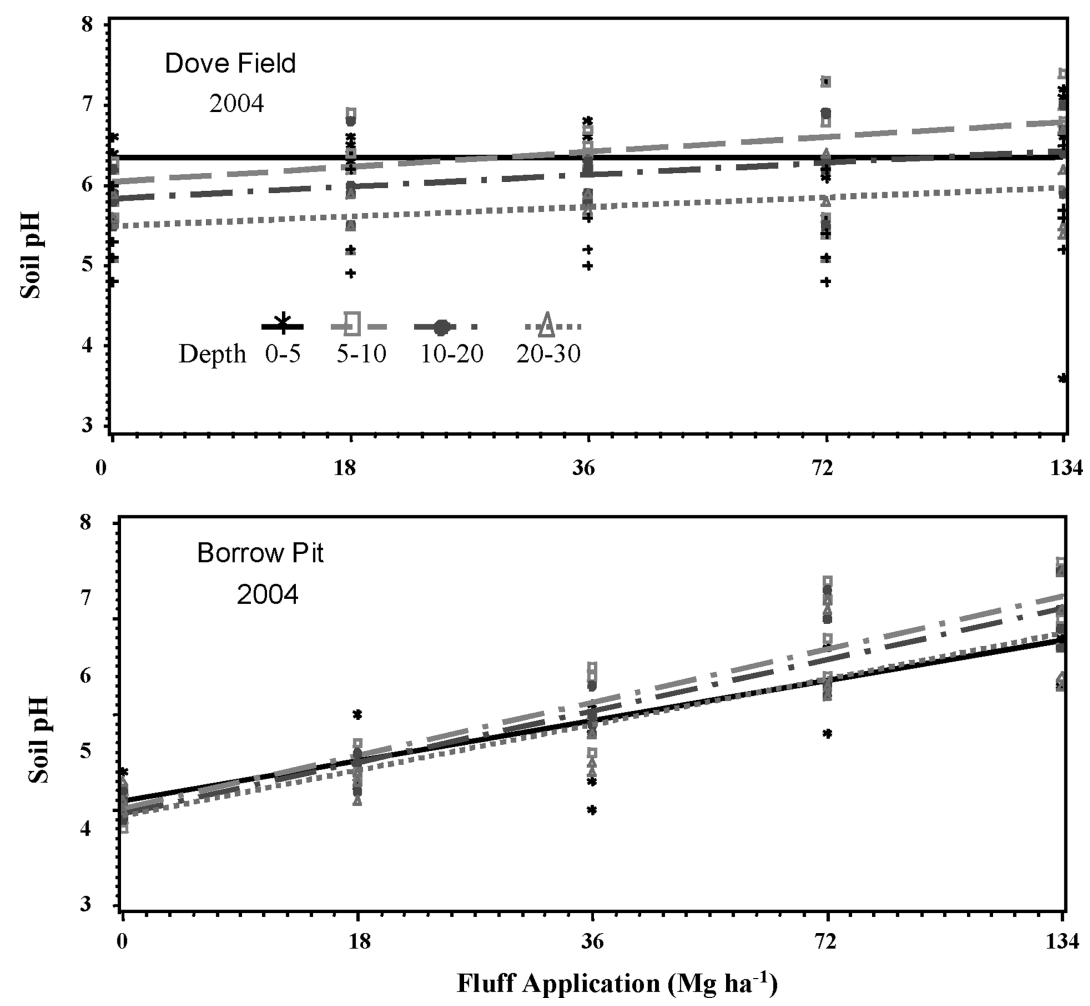

Figure 2. Regression relationships of Fluff application rate to soil $\mathrm{pH}$ measured at $0-5$, 5-10, 10-20, and 20-30 cm soil depth at the Dove Field and Borrow Pit study sites in 2004 (See Table 6 for regression equations and $r^{2}$ values).

In the second year, a less dramatic impact of the Fluff on the soil $\mathrm{pH}$ was noted at the Dove Field, with only a small impact of the Fluff on soil $\mathrm{pH}$ observed (Figure 2). By the time sampling occurred following the second growing season after application, only the 5-10 and the $10-20 \mathrm{~cm}$ depth had a significant regression line for Fluff application vs. soil pH level (Table 6). This was likely due to natural processes that decrease soil $\mathrm{pH}$, such as decomposition of organic matter and leaching with natural precipitation (Potash and Phosphate Inst., 2003). However, at the Borrow Pit, while $\mathrm{pH}$ was lower than observed the previous year, large differences in the soil $\mathrm{pH}$ level were still noted at all soil depths (Figure 2). Significant linear regression lines were observed at all soil depths measured (Table 6). This indicated that the Fluff may have had a more lasting impact on soil conditions under these extreme conditions, helping the soil to develop a balance that would be more conducive for plant establishment and growth.

The soil $\mathrm{C}$ and $\mathrm{N}$ concentration was measured at both study sites. Soil $\mathrm{C}$ and $\mathrm{N}$ concentration is one of the most important factors for assessing soil 
quality (Wienhold et al., 2004) that impacts soil physical, chemical, and biological functions of the soil. The buildup of soil $\mathrm{C}$ can be essential to the long term health of the system. The soil $\mathrm{C}$ concentration after the first growing season was highly variable and inconsistent, resulting in unreliable data (data not shown). Also, since the Fluff consists of non-composted material, the immediate decomposition of the Fluff could potentially cause variability in the soil samples which would not be reflective of the actual soil condition. The impact of the Fluff application on soil $\mathrm{C}$ and $\mathrm{N}$ concentration for the soil samples taken after the second growing season are shown in Figures 3 and 4.

At the Dove Field, where no Fluff was applied, the soil C concentration was approximately $13 \mathrm{~g} \mathrm{~kg}^{-1}$ in the surface $0-5 \mathrm{~cm}$ depth and declined with increasing soil depth, down to $3.3 \mathrm{~g} \mathrm{~kg}^{-1}$ at the $30-60 \mathrm{~cm}$ soil depth layer (Figure 3). Soil N concentration was found to be $0.6 \mathrm{~g} \mathrm{~kg}^{-1}$ in the soil surface $(0-5 \mathrm{~cm})$ and fell to $0.2 \mathrm{~g} \mathrm{~kg}^{-1}$ at the $30-60 \mathrm{~cm}$ soil depth layer. These levels of soil $\mathrm{C}$ and $\mathrm{N}$ are in the range expected for degraded sandy loam soils in the
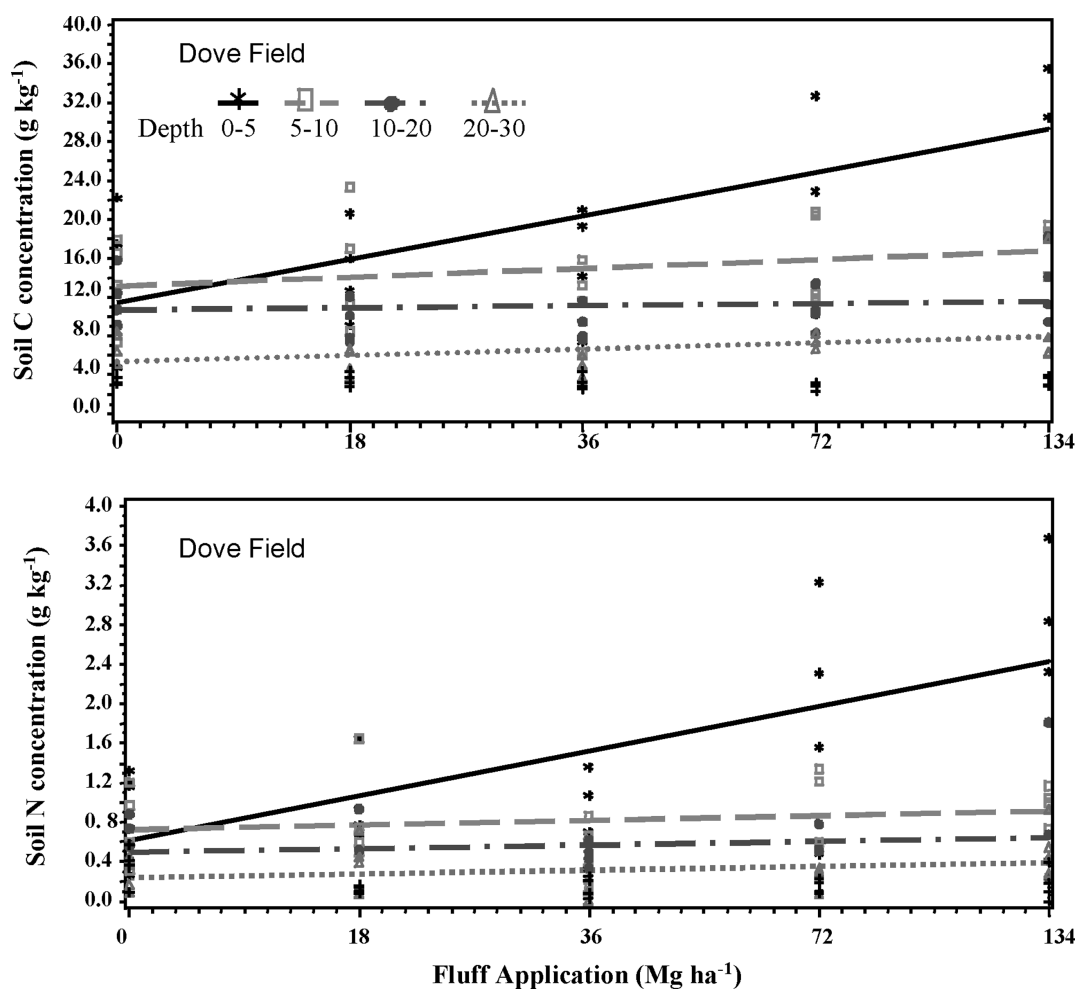

Figure 3. Regression relationships of Fluff application rate to soil $\mathrm{C}$ and $\mathrm{N}$ concentration measured at 0-5, 5-10, 10-20, and 20-30 cm soil depth at the Dove Field study site in 2004 (See Table 7 for regression equations and $r^{2}$ values). 

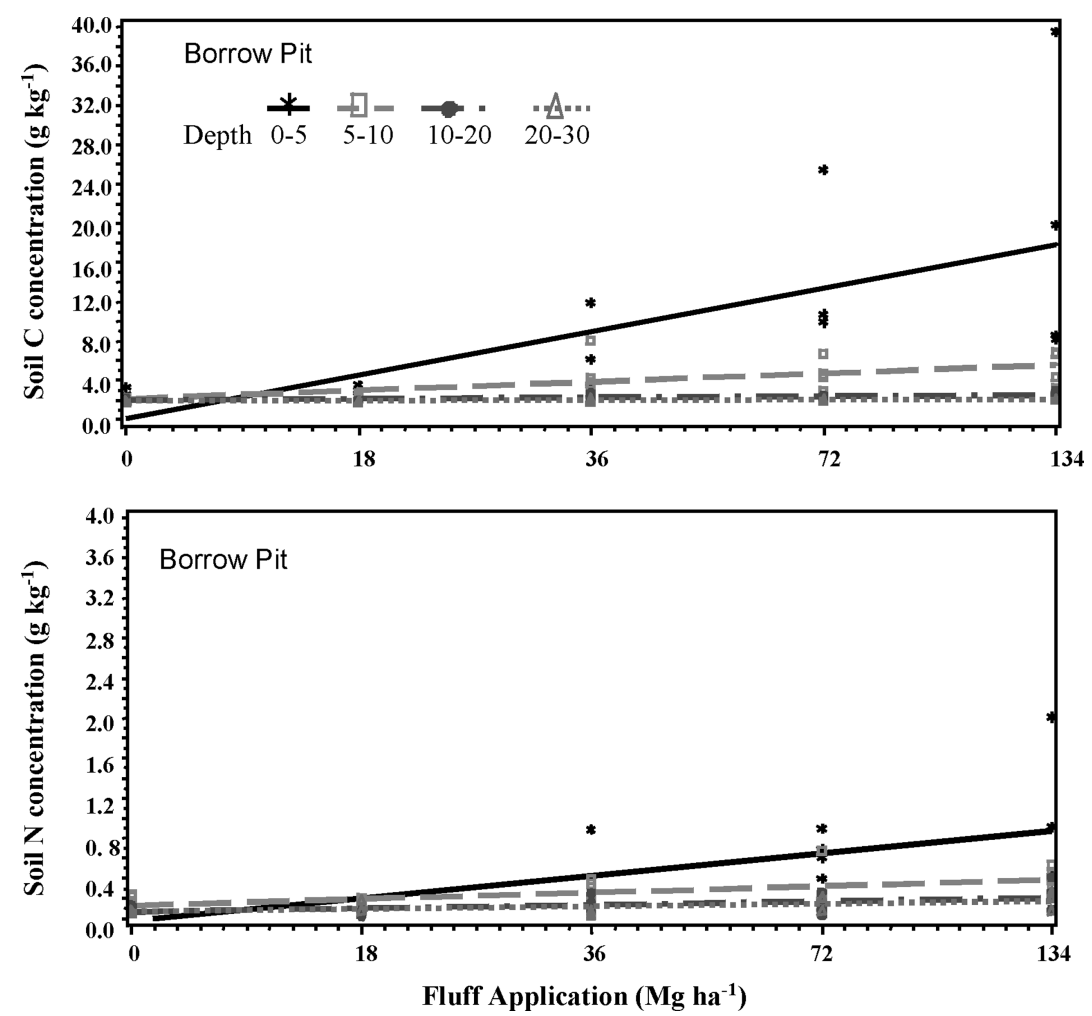

Figure 4. Regression relationships of Fluff application rate to soil $\mathrm{C}$ and $\mathrm{N}$ concentration measured at $0-5,5-10,10-20$, and $20-30 \mathrm{~cm}$ soil depth at the Borrow Pit study site in 2004 (See Table 7 for regression equations and $r^{2}$ values).

region. The application of Fluff had a large impact on the soil concentration of $C$ in the soil surface $(0-5 \mathrm{~cm})$, increasing with increasing Fluff application up to approximately $39 \mathrm{~g} \mathrm{~kg}^{-1}$ (Table 7). Likewise, a significant linear regression was observed for soil $\mathrm{N}$, increasing with increasing Fluff application rate (Table 7). No significant impact from the application of Fluff was observed for soil concentration of $\mathrm{C}$ and $\mathrm{N}$ below the $0-5 \mathrm{~cm}$ depth at this location.

In the highly degraded Borrow Pit site, the soil concentrations of $\mathrm{C}$ and $\mathrm{N}$ were extremely low where no Fluff had been applied, with a $\mathrm{C}$ concentration of $2.2 \mathrm{~g} \mathrm{~kg}^{-1}$ and $\mathrm{N}$ concentration of $0.1 \mathrm{~g} \mathrm{~kg}^{-1}$. At this site, little difference was observed through the soil profile for $\mathrm{C}$ and $\mathrm{N}$ concentration due to the extremely low concentrations and the lack of any plant growth. At this location, the application of Fluff revealed a significant influence on soil $\mathrm{C}$ in the soil surface (0-5 cm depth), with an increase to approximately $20.2 \mathrm{~g} \mathrm{~kg}^{-1}$ with the application of $143 \mathrm{Mg} \mathrm{ha}^{-1}$ of Fluff (Figure 4). Likewise, the soil $\mathrm{N}$ level was increased with increasing Fluff application, with a soil $\mathrm{N}$ concentration of 
approximately $1.0 \mathrm{~g} \mathrm{~kg}^{-1}$ with the $143 \mathrm{Mg} \mathrm{ha}^{-1}$ application rate. The $\mathrm{C}: \mathrm{N}$ ratio of the soil at this depth was approximately 20 . This would generally indicate that the soil organic matter level would result in further decomposition, but in this case the $\mathrm{C}: \mathrm{N}$ ratio was not substantially different than was observed in the initial soil level, with a $\mathrm{C}: \mathrm{N}$ ratio of 22 . Regardless, the $\mathrm{C}: \mathrm{N}$ ratio of the soil indicates that it was much more stable than that of the non-composted Fluff that was originally applied to the soil. This level of increase in soil C and $\mathrm{N}$ at this depth demonstrated an improvement in soil condition and is in the range that would be considered excellent for a sandy loam soil in this region.

Unlike the Dove Field soil, significant linear regression was observed for increasing soil $\mathrm{C}$ and $\mathrm{N}$ with increasing Fluff application below the $0-5 \mathrm{~cm}$ depth (Table 7, Figure 4). While small compared to the impact that was observed in the $0-5 \mathrm{~cm}$ depth, a distinct increase in both $\mathrm{C}$ and $\mathrm{N}$ concentration could be observed with the increasing application of Fluff at the 5-10, 10-20, and 20-30 $\mathrm{cm}$ depth increments (Table 7, Figure 4). This increase could be partially caused by the movement of soluble $\mathrm{C}$ and $\mathrm{N}$ compounds deeper into the soil profile. However, this increase was most likely the result of increased plant rooting with the establishment of the native grasses. The increased grass biomass observed with increased Fluff application rate (Table 2) would have been accompanied by increased root biomass below the soil surface. This increased rooting would have resulted in increased organic matter input into the soil. Because this soil was so devoid of organic $\mathrm{C}$, the improved rooting was detectable as an increase in the soil $\mathrm{C}$ concentration levels. Organic $\mathrm{C}$, fixed by the plant through photosynthesis, and $\mathrm{N}$ that was taken up in the $0-5 \mathrm{~cm}$ depth would be moved deeper into the soil profile with root growth. This improvement in soil $\mathrm{C}$ and $\mathrm{N}$ not only at the soil surface where Fluff was incorporated, but deeper into the soil profile would be invaluable to improving the soil/plant environment on a highly disturbed soil, such as was used in this study.

\section{CONCLUSIONS}

On marginal lands such as degraded US Army training areas, organic amendments can be very effective when used to enhance vegetation establishment. In this study, the use of non-composted Fluff material was examined as a possible organic amendment for improving degraded soil. The addition of the Fluff resulted in a decrease in the soil bulk density in the soil surface $(0-5 \mathrm{~cm})$. This improved soil physical condition was also noted in soil sampling that was conducted after the second growing season indicating that the improved soil physical condition should persist. The addition of the Fluff increased soil $\mathrm{pH}$ in the soil profile down to $60-\mathrm{cm}$, and increased the soil availability of plant nutrients in the soil surface. After the second growing season, an increased level of soil $\mathrm{C}$ and $\mathrm{N}$ concentration was observed with the increased application of Fluff. 
The results of this study indicated that the application of an non-composted organic amendment to degraded soil would improve soil conditions and provide a healthier soil environment for plant establishment. The improved conditions were most prominent on the more highly degraded soil site, indicating that the more degraded the soil the higher the potential benefit from the addition of organic amendments (even non-composted organic amendments).

\section{ACKNOWLEDGMENTS}

We would like to thank Jerry Carrington, Marlin Siegford, and Dr. Stephen Prior of the USDA-ARS National Soil Dynamics Lab for their expertise in data collection; and Pat Kemme of ERDC-CERL for her assistance in performing the initial sampling and analysis of the Fluff. This study was funded by the United States Army Office of the Directorate of Environmental Programs (DAIM), Assistant Chief of Staff (Installation Management); U.S. Army Forces Command; and Congressional Plus Up.

\section{REFERENCES}

Auburn University Soil Testing. 2005. Soil Testing and Plant Analysis. http://www.ag.auburn.edu/agrn/spmenu.htm (Verified September 23, 2005)

Bouldin \& Lawson, Inc. 2000. Process of transforming household garbage into useful material. United States Patent 6017475. Date issued 25 January 2000.

Busby, R. R. 2003. Suitability of a municipal solid waste byproduct as a soil amendment for reestablishing native grasses on disturbed Army training lands, M.S. Thesis, University of Illinois, Urbana-Champaign.

Busby, R., D. L. Gebhart, and H. A. Torbert. 2006. Effects of an uncomposted municipal waste processing byproduct on prairie grass establishment. Agronomy Journal 98(4): 1073-1080.

Croxton, S. D., J. L. Sibley, W. Lu, and M. Schaefer. 2004. Evaluation of composted household garbage as a horticultural substrate. In Proceeding of the Southern Nursery Association, ed. Bryson L. James, 296299, http://www.sna.org/research/04proceedings/ (Verified September 27, 2005).

Department of Defense (DoD). 2001. Base structure report: Fiscal year 2001 baseline. Office of the Deputy Under Secretary of Defense, Installations and Environment. Washington, D.C.

Drake, L. D. 1980. Erosion control with prairie grasses in Iowa strip-mine reclamation. In Proceedings of the 7th North American Prairie Conference, 4-6 August 1980, ed. C. L. Kucera, 189-197. Springfield, Missouri.

Edwards, J. H. 1997. Composition and uses of uncomposted wastepaper and other organics. In Agricultural uses of byproducts and wastes, 
eds. J. E. Rechcigl and H. C. MacKinnon, 163-184. American Chemical Society: Washington, DC.

Glinski J., and J. Lipiec. 1990. Soil physical condition. CRC Press, Inc. Boca Raton, FL.

Jung, G. A., J. A. Shaffer, and W. L. Stout. 1988. Switchgrass and big bluestem response to amendments on strongly acid soil. Agronomy Journal 80: 669676.

Hue, N. V., and C. E. Evans. 1986. Procedures used for soil and plant analysis by the Auburn University Soil Testing Laboratory. Auburn University: Auburn, AL.

Karlen, D. L., J. R. Russell, and A. P. Mallarino. 1998. A system engineering approach for utilizing animal manure. In Animal waste utilization: Effective use of manure as a soil resource, eds. J. L. Hatfield and B. A. Stewart, 283315. Ann Arbor Press: Chelsea, MI.

Levy, D. B., E. F. Redente, and G. D. Uphoff. 1999. Evaluating phytotoxicity of $\mathrm{Pb}-\mathrm{Zn}$ tailings to big bluestem (Andropogon gerardii Vitman) and switchgrass (Panicum virgatum L.). Soil Science 164(6): 363-375.

Littel, R. C., G. A. Milliken, W. W. Stroup, and R. D. Wolfinger. 1996. SAS system for mixed models. SAS Institute, Inc.: Cary, North Carolina.

McLean, E. O. 1982. Soil pH and lime requirement. In Methods of soil analysis: Part 2, 2nd ed., eds. A. L. Page et al., 199-224. ASA, SSSA: Madison, WI.

Mehlich, A. 1953. Determinations of $\mathrm{P}, \mathrm{Ca}, \mathrm{Mg}$., $\mathrm{K}, \mathrm{Na}$, and $\mathrm{NH}_{4}$ by North Carolina soil testing laboratories. N.C. State University: Raleigh, NC.

Potash and Phosphate Institute. 2003. Soil fertility manual. Potash \& Phosphate Institute and the Foundation for Agronomic Research. Norcross, GA.

Prior, S. A., G. B. Runion, H. A. Torbert, and D. C. Erbach. 2004. A hydraulic coring system for soil-root studies. Agronomy Journal 96: 1202-1205.

Skeel, V. A., and D. J. Gibson. 1996. Physiological performance of Andropogon gerardii, Panicum virgatum, and Sorghastrum nutans on reclaimed mine spoil. Restoration Ecology 4(4): 355-367.

Solid Waste Annual Reporting (SWARweb) 2003. United States Department of Defense. Available URL: https://www.swar.intecwash.navy.mil/ webtogo/WLTop [Verified November 18, 2005].

U.S. Government 40 C.F.R. Part 503. 1999. Standards for the use or disposal of sewage sludge.United States Code of Federal Regulations Title 40 Part 503, 1999 edition. College Park, MD.

Wienhold, B. J., Andrews, S. S., Karlen, D. L. 2004. Soil quality: a review of the science and experiences in the USA. Environment Geochemical Health. 26(2-3): 89-95.

Wilson, S. D., and A. K. Gerry. 1995. Strategies for mixed-grass prairie restoration: herbicide, tilling, and nitrogen manipulation. Restoration Ecology 3(4): 290-298. 